\title{
Unusual but Honest: Kamala Das and Confessional Poetry
}

\author{
Dr. Mohammad Hadi SAMENI ${ }^{1, *}$, Faranak SHAHMORADI ${ }^{2}$ \\ ${ }^{1}$ Department of English, School of Medicine, Jahrom University of Medical Sciences, \\ Jahrom, Iran \\ ${ }^{2}$ Department of English, Ghorveh Branch, Islamic Azad University, Ghorveh, Iran \\ Faranak_shahmoradi@yahoo.com \\ *Corresponding Author: Sameni@jums.ac.ir
}

\begin{abstract}
Many critics from India, such as Ramesh Kumar Gupta, C. Santhosh Kumar, A. Selvalakshmi, Z. F. Molvi, describe the poetry of Kamala Das as being unusual, while the poet believes that she writes with 'candour' about her experiences of womanhood. Speaking of her poetry as 'unusual' is an expected reader's response to poems written in the confessional mode that transgress accepted norms of tradition, conventions and culture in her society. Confessional constitutes an interesting dimension of women's writing, in which the poets uncover confidentialities that bond her private and public spheres together. This paper is an investigation into the poetry of Kamala Das (1934-2009), the prolific Indian woman writer of the twentieth century to explicate confessional elements in her poetry. Das borrows this style of writing from her contemporary American writers and employs it as a means of articulation, negotiation and resistance through projecting the self.
\end{abstract}

Keywords: English Poetry, Indian Writing, Women Writers, Confessional Mode

\section{Introduction}

...O man, O selfish being, [shameless] do not say [my] poem is a cause for shame have you ever known that in this cage the space is narrow and narrow?

Say not [my] poem [is] sin...let me have a chalice of this sin and shame... O man throw away the account of your reputation disgrace has offered me a giddy enjoyment...

Extract from "Rebellion" by F. Farrokhzad [1]

Lines quoted above, composed by the Iranian writer, Forough Farrokhzad, can be used as a proper frame of reference for this paper. The epigraph implies a major concern of women, namely the lack of space which has both physical and mental implications. "Rebellion" is a strong defence of poetry written by Farrokhzad in which she overtly protests against the traditional role allotted to women, namely domesticity. In this poem, she condemns the stereotype that refers her poems as "sin" and forbids women from writing. This is the common plague faced by many women writers including Kamala Das that male members of their families - a father figure in the above poem- think of their writing as sin. Nonetheless, the writer is not interested to give up her choice of writing poetry. This is reflected in the line she informs her interest to "have a chalice of this sin and shame." Furthermore, the same line can be interpreted as a declaration of her identity as a writer who wants to break the narrow space by articulating, interrogating and resisting man-made stereotypes and inequalities. 


\section{1. About Das}

Kamala Das (1934-2009), was a prolific Indian woman writer of the twentieth century. She did not have a long term formal education, but literature had a very special place in her family. Her mother a well-known Malayalam writer and her great uncle was a leading poet and philosopher. In addition, she had access to a library of sacred scripts maintained by her matrilineal Nair community. In such an environment, Das grew soon as a capable writer both in English and Malayalam [2].

\section{2. Background}

Art is the extension of life for Kamala Das and a means of expression. Being a modernist writer, Das chooses confessional poetry as the frame for her writing. Through this literary style, she publishes her unspoken words and confidentialities of her life which create much controversy and dispute in the news media. This shocking quality of her writing is frequently attributed to the influence of the school of confessional poetry developed by American writers during the 1950s and 1960s. To name a few of forerunners of this literary school, figures including John Berryman, Robert Lowell, Anne Sexton, Sylvia Plath, and W. D. Snodgrass can be mentioned. Critic N. Ramadevi believes that this poetry is a by-product of popularisation of psychological theories and studies of Freud and Jung, and the feminist movement [3].

It should be noted that M. L. Rosenthal has been the first person who coined the term 'confessional.' He introduced it in 1959 while publishing his article entitled "Poetry as Confession," in The Nation. The article was a review of Robert Lowell's Life Studies, in which Rosenthal mentioned that the poet had removed the mask that always hid the poet's "actual face" [4]. Rosenthal's explanation suggested that writer was not expected to share certain personal experiences with the public. However, publicizing them would make the quality of this type of writing similar to that of a confession. According to A. N. Dwivedi: "All confessional poetry springs from the need to confess and so each poem cast in this mode is in some way, a declaration of dependence, or of guilt, or of anguish and sufferings" [5]. One more reason to write in confessional mood is to raise voice against insults the poet experienced in her life. In this sense, it would be both the means of exhibiting the wounded-self injured by social institutions and a therapy to overcome the mental illness developed in the writer's psyche. Sexton once said that "poetry led me by the hand out of madness. I am hoping I can show others that route" [6]. Another application of this poetry is the assertion of self which is achieved through the recurring technique of monitoring or interrogating the self. V. T. Usha believes that such attention to writing is the direct effect of the Freudian psychoanalysis "where the verbalisation of individual experience was considered therapeutic" [7].

\section{Use of Confessional Elements by Das}

Confessional elements combine a range of themes including familial issues, physical and mental illnesses, despondence, addiction, and articulating on those topics such as body and sexuality, which are taboos. R. J. Kalpana [8] believes that writing about the body breaks down all protective barriers of politeness which are the touchstone of a civilised patriarchal society.

\section{1. Craving for Paternal Love}

Expecting to receive love from the father figure is an important theme in the poetry Kamala Das. This section highlights views of Das on her father and her exposure of personal and 
confidential issues. "My Father's Death" is a long poem in which Das explains her relationship with her father:

\author{
Only the insincere shed tears \\ At my father's death, those who came \\ To get photographed with the corpse... \\ Only those who lost their yearly \\ Baksheesh wept at my father's death. \\ He was generous with money \\ As generous as I was with \\ Love. There was a cloud of tension \\ Between him and me... \\ Only in coma \\ Did he seem close to me, and I \\ Whispered into his ears that I \\ Loved him although I was bad, a bad daughter, a writer of tales that \\ Hurt, but in the task of loving \\ The bad ones were the ablest, yes \\ You should have hugged me, father... [9]
}

Speaking about the generosity of her father, Das, ironically, suggests that love cannot be bought by money. Yet, her generosity with love also fails to grant her true love, because her expectation of love remains unrequited, due to her father's attitude towards her writing. Being 'bad' implies that her father, as a member of patriarchal structure, does not recognise the role of writer for his daughter.

"Next to Indira Gandhi" reflects more about the emotions of Das towards her father. It reveals how the absence of love can form a rebellious attitude in a young daughter:

Did you want me?

Did you ever want a daughter?

Did I disappoint you much?

With my skin as dark as yours

You are dead, nobody fears you now... [10]

In the above lines, Das, resentfully, accuses her father of alienation from his own culture and asks him if he is disappointed in her skin colour. Further, Das reveals the patriarchal mind-set in her father by asking whether he "ever want(ed) a daughter." She does not show sympathy for her father's death because of the frosty nature of their relationship. "Fears" denote a false respect, if any, for her father. In "A Requiem for my Father," it appears that Das has

positively changed her opinion towards her father, when she says: "I would have gladly changed places with you, father/I was never afraid to die" [11]. There is another implication; Das disappointedly states that her life has not been better than death. Therefore, she is ready to embrace death willingly, and this death wish links Das to other confessional poets. "Too Late for Making Up" is another poem which depicts the lack of bonding between Das and her father.

Father, it's too late for making up with you

The time for debates on honour is over now

You won, didn't you...

You turned cold on the drawing room floor

Colder than your heart ever was...

Should I have loved you, father

More than I did

That wasn't so easy to do... [12] 
The poem indicates the yawning gap between the members of two subsequent generations; father and his daughter. Their conflicts never reach a compromise because each of them holds firmly to their own beliefs. Values which are important and honour-bound to her father deprive him from making positive emotional ties to his daughter and so she does not regret her father's death. The line, "You won..." proves that Das' father never responded to his daughter's yearning for paternal love.

\section{2. Moaning the Loss of Love in Conjugal Life}

On this particular issue, Das expresses her unfulfilled emotion of love in marriage. Meanwhile, she articulates her views on the institution from a woman's perspective that is contradictory to the prevalent social trends. In "An Introduction," Das reflects on her physical maturity and condemns the arranged marriage due to the absence of two aspects - mental readiness for the change to come and love. The poem suggests that even in marriage, sex without consent is equivalent to rape.

I was child, and later they

Told me I grow, for I became tall, my limbs

Swelled and one or two places sprouted hair. When

I asked for love, not knowing what else to ask

For, he drew a youth of sixteen into the

Bedroom and closed the door. He did not beat me

But my sad woman-body felt so beaten.

The weight of my breasts and womb crushed me. I shrank

Pitifully... [13]

For Das, marriage becomes a trap that she had no escape from, especially at such a young age. Her romantic notions of marriage never materialised as she sought that elusive emotion called 'love.' Meanwhile, her husband's attention is only focussed on his own needs. He succeeds in fulfilling his conjugal right, unmindful of the fact that his young wife wants love and not merely sex. Das discloses her thoughts and experiences in this poem. However, she is very fair in her judgement of her husband when she says "he did not beat me" but her inner confusion due to her unfulfilled desires make her objectify the entire relationship. Das, in the last couple of lines, suggests that being a woman has lowered her as an individual. Hence, she tries to negate this role in the following lines: "Then I wore a shirt and my / Brother's trousers, cut my hair short and ignored / My womanliness... [14]. Das, in these lines, claims her emancipation by assailing the prevalent norms of dress code and hair style for women. "The Old Playhouse" abounds in multiple confessional elements. As its central theme, however, the poem depicts matrimonial problems of a young girl within the context of an arranged marriage.

$$
\begin{gathered}
\text { It was not to gather knowledge } \\
\text { Of yet another man that I came to you but to learn... } \\
\text { You were pleased } \\
\text { With my body's responses, its weather, its usual shallow - Convulsions... } \\
\text { I was taught to break saccharine into your tea and } \\
\text { To offer at the right moment the vitamins... [15] }
\end{gathered}
$$

The first two lines describe her partial knowledge of marriage and its attendant duties at the time of getting married. This indicates that her conjugal life started at young age. It is for this reason, she has more expectations from her husband to play the role of a father too. Instead, he makes the space more limited for her than it was earlier - being treated as a sexual object and getting caught up in domesticity as an unpaid servant in the company of an old man. The last two lines perfectly match Francis Bacon's statement in "Of Marriage and Single Life:" "Wives are young men's mistresses; companions for middle age; and old men's nurses" [16]. 
Dwivedi labels the poem a reflection of illicit sexual love. He says, the "wife is treated no better than a hireling." The implication is again rape within marriage in the absence of the wife's consent and consciousness [17].

The subsequent lines from the same poem indicate that marriage to a selfish husband has lowered her pride and given her a loss of identity, will and reason:

\section{Cowering}

Beneath your monstrous ego I ate the magic loaf and

Became a dwarf. I lost my will and reason, to tell your

Questions I mumbled incoherent replies.

There is

No more singing, no more a dance, my mind is an old

Playhouse with all its lights put out. [18]

Das clearly points to the unequal nature of her relationship with her husband when she speaks of his ego. It is a similar experience with her father. Both the men represent patriarchy which puts women in the 'proper' position, below men and undervalues her. It leads to her loss of will and reason as well as her mumbling which denotes a pause in her voicing. As a matter of fact, the 'lights' in her mind are put out. The symbolism behind the image of 'light' suggests a range of meanings. Marcus J. Borg believes that: "The symbolism of light and darkness is ancient, archetypal and cross-cultural. It has many rich resonances of meaning. Darkness is associated with blindness, night, sleep, cold, gloom, despair, lostness, chaos, death, danger and yearning for the dawn. It is a striking image of the human condition. Light is seen as the antidote to the above, and is thus an image of salvation. In the light, one is awake, able to see and find one's way; it is associated with relief and rejoicing that the night is over; in the light one is safe and warm. In the light there is life." [19]

\section{3. Communicating Passion in Matrimony}

One of the confessional aspects of the poetry of Das is publicising the issue of sex in marriage. Extracts given below are typical examples on this theme. "The Freaks" from Summer in Calcutta is a good example of Kamala Das' view on this matter. It depicts the conjugal life as a mechanical and soulless tie:

He talks, turning a sun-stained

Cheek to me, his mouth, a dark

Cavern, where stalactites of

Uneven teeth gleam, his right

Hand on my knee, while our minds

Are willed to race towards love;

But, they only wander, tripping

Idly over puddles of

Desire... Can't this man with

Nimble finger-tips unleash

Nothing more alive than the

Skin's lazy hungers...

I am a freak. It's only

To save my face, I flaunt, at

Times, a grand, flamboyant lust. [20]

Das, unfulfilled by love, describes her communication within marriage as unpleasant and disgusting confined to physical desires. In a candid manner, she states that she "flaunts a flamboyant lust, only to save [her] face." According to Ramadevi, Das' failure to find love leaves her in the claustrophobic world of the wounded self. It makes the writer's struggle in 
search of identity, a central theme of her poems. Ramadevi believes that "The Old Playhouse," "An Introduction," "The Freaks," and "The Looking Glass" are examples of the poet's wounded self [21]. "In Love" also reflects on sexuality within marriage, in the absence of love:

...when mouth on

Mouth, I lie, ignoring my poor

Moody mind, while pleasure

With deliberate gaiety

Trumpets harshly into the

Silence of the room... [22]

By contrasting two distinctly different aspects of sound - the loud noise of the trumpet and silence, Das covertly states that only in the interstice of physical pleasure her recollection of lost identity becomes dull, at least for fleeting moments.

\section{4. Searching for Sex, Love and Identity}

Dissatisfied with her own married life, because she did not get the intellectual partnership she yearned for, Das sought relationships with men outside her marriage. She was seeking not just sexual liberties but a deep emotional bond and an answer to her unfulfilled desires. Das turns to other men when her demand for love is not fulfilled within her own marriage. It should be mentioned that marriage in the Nair community is not basically a tie of affection, but a social contract in which the man provides sexual service. Hence, he has no power and right inside the house and upon the wish of the wife this contract may be terminated at any time. The husband's emotional bonds are cleaved to children born to his sisters, and they are considered his own blood. In his sister's home, he is the maternal uncle who, in Malayalam, is referred to as the "karanavan"6 [23]. Das protests against this social obligation in "Substitute" by juxtaposing and rationalising her loveless life with her illicit affairs.

Our bodies after love-making

Turned away, rejecting.

Our words began to sound

Like clatter of swords in fight.

After that love became a swivel-door,

When one went, out, another came in,

Then I lost count, for always in my arms

Was a substitute for a substitute. [24]

The poem shows that moments of unity between the couple are transitory, because love has been replaced by love-making which implies selfishness rather than devotion to marriage. The couple blame each other, instead of exchanging words of affection. Hence, the period of devotion or commitment to matrimonial tie is finished soon. Losing her trust in her man's love, the woman retaliates by seeking physical satisfaction outside marriage. The last line implies that, it is the poet who decides her affairs, which signifies the poet's self-assertion.

The poem "Glass," reveals the intensification of the identity crisis in the writer. Deprived of masculine love, Das depicts a vacant place in her heart that only marital love can fill. The failure of her husband to supply this need drives her to extramarital affairs.

I went to him for half an hour

As pure woman, pure misery

Fragile glass, breaking

Crumbling....

With a cheap toy's indifference

I enter other's

Lives, and 
Make of every trap of lust

A temporary home...

... I've misplaced a father

Somewhere, and I look

For him now everywhere. [25]

In the above lines, the poet, ironically, criticises the moral code of purity for woman to her misery. Further, the "fragile glass" of the third line depicts the writer's brittle mind. It can also be interpreted as a metaphoric reference to the broken heart of the poet as Dwivedi believes [26]. Moreover, due to the link between the word "glass" and "pure," the meaning of this symbol can be extended to female sexuality, too. In certain cultures, glass is the symbol of a woman's virginity. On the night of wedding, the groom stomps on a wine glass wrapped in a cloth. Breaking the glass indicates the transition of the bride from girlhood to womanhood. A similar tradition can be explored in the Yiddish version of Cinderella. The prince of this version identifies the virgin Cinderella from the non-virgin claimants by asking them to try the glass shoes. Except for Cinderella's shoe, the rest of the shoes break on trial. Hence, Das' purity as a woman committed to her marital life is broken by her involvement in extramarital affairs, where she is treated as a cheap object. [27]

\section{5. Frustration with Love}

Being annoyed with sexual experiences that did not always come to happy ending, especially when it takes place in the context of her partners' selfishness, Das gets frustrated with love. "Composition" is one of the long poems written by Das with multi-faceted confessional elements. The writer's frustration with love is evident in the following lines:

I have replaced love with guilt and discovered

that both love and hate are

involvements...

Love

I no longer need [28]

Love and sex are interrelated concepts for Das. She does not gain true love in marriage; instead she becomes the victim of her partner's "brutality of sex" [29]. Therefore, sexuality in marriage is disgusting and provokes a sense of hatred towards her husband and those who trapped her in marriage. Das' search for love outside marriage also proves to be futile, since her extra marital relationships give her only sex. It adds to her problems and fills her with the feeling of guilt and self-rejection. Hence she realises that both, love and hate bring her only trouble. In "Captive," Das questions the concept of love and calls it slavery. This poem depicts the melancholic mind of the writer, even while it describes how love has degenerated into lust.

My love is an empty gift, a gilded

empty container, good for show, nothing else...

...what have

We had, after all, between us but the womb's blinded hunger... [30]

In the above lines, Das compares her love to a gift which is shining, as if it is covered in gold, but contains nothing within it. Therefore, she symbolically points to her empty life and love. For this reason, asserting the self is an integral part of writings of confessional poets such as Kamala Das.

\section{6. Speaking of Sex}


Some poems written by Das on her physical relationships reflect the feelings of sexual exploitation within and outside their marriage. In "Spoiling the Name," Das begins with the problem of identity crisis and indirectly points to her sexual exploitation.

I have a name, had it for thirty

Years, chosen by someone else

Convenience, but when you say

Don't spoil your name, I feel I

Must laugh, for I know I have a life

To be lived, and each nameless

Corpuscle in me, has its life to

Be lived...

Where I go to meet a man

Who gives me nothing but himself, who

Calls me in his private hours

By no names... [31]

By taking a radical stand, Das has made the poem a protest or revenge against the accepted values of her family. Further, in the last four lines quoted above, the poet, ironically, mentions that men have little resonance for the identity of a woman; the man who meets her is every man who looks for physical satisfaction. Parallel to the above theme there is a reference to 'naming.' The issue of naming, raised by Das, reflects the views of Mary Daly in her book, The Church and the Second Sex. Citing Daly, Sarah Lucia Hoagland and Marilyn Frye believe that naming implies the locus of power: "In order to understand the implication of this process it is necessary to grasp the fundamental fact that women have had the power of naming stolen from us. Women have not been free to use their own power to name themselves, the world, or God. The old naming was not the product of dialogue -- a fact inadvertently admitted in the Genesis story of Adam's naming the animals and the woman. Women are now realising that the universal imposing of names by men has been false ... To exist humanly is to name the self, the world and God. " [32]

\section{7. Confronting Despondence, Distress and Anxiety}

Despondence is a characteristic emotional response found in the poetry of Das. This emotion also pinpoints highly personal elements in the life of the writer. The melancholic mood includes sadness and anguish, depression, dejection, and helplessness. "Too Early the Autumn Sights" reflects the feeling of dejection in Das, shortly after her marriage.

Can't you see how at the end of day

I pause, alone at last

With terror,

And shut my eyes, my ears,

My timid mouth? ...

Too early the autumn sights

Have come, too soon my lips

Have lost their hunger, too soon

The singing birds have

Left. [33]

Autumn is the grey season, depicted by falling leaves and is a prelude to the onset of winter. The title of the poem ironically suggests that Das, at the prime of her youth, loses her happiness and is caught in a paralysed life. The poet accentuates this idea by juxtaposing the "singing birds" whose melodies symbolise freedom, lack of restraint, happiness, delight and communication through their tuneful lyrics. Das, shutting her eyes, ears and mouth, clearly indicates the termination of her relationship with her husband. This is the reason for her 
loneliness and her hours spent in terror. "The Sunshine Cat" also refers to the expectation of love by Das. Her quest is left unfulfilled both within and outside marriage. The poem can be interpreted as the versification of the poet's severe despondence as she refers to her sexual humiliation.

They did this to her, the men who knew her, the man

She loved, who loved her not enough...

...the husband who neither loved nor

Used her, but was a ruthless watcher, and the band

Of cynics she turned to, clinging to their chests where

New hair sprouted like great-winged moths, burrowing her

Face into their smells and their young lusts... [34]

The poem reflects the writer's mental distress as a result of her interactions with the masculine world around her. In this poem, Das uses the second person persona to keep the readers at a distance from emotional sympathy with characters and actions, in order to increase their level of consciousness to better understand and analyse the poem. This technique first used by Bertolt Brecht is a theatrical device known as the "distancing technique or the distancing effect -the original word in German is Verfremdungseffekt." [35] This is done to alienate the audience from emotional attachment to the characters and scenes in a play. This technique enables the audience to scrutinise the events on stage with conscious and thoughtful consideration [36].

\section{8. Sense of Inadequacy}

The sensitive mind of a confessional poet is often involved in observing and monitoring the subjective self. In "The Dance of the Eunuchs," Das reveals such sensitivity by thinking of her identity as freakish.

It was hot, so hot, before the eunuchs came

To dance, with skirts going round and round... They danced, oh, they danced till they bled... there were green

Tattoos on their chicks...

Their voices

Were harsh, their songs melancholy; they sang of

Lovers dying and of children left unborn...

Some beat their drums; others beat their sorry breasts,

And wailed, and writhed in vacant ecstasy. They

Were thin in limbs and dry; like half burnt logs from

Funeral pyres, a drought and rottenness

Were in each of them. [37]

The poem begins with a dance of the eunuchs until blood oozes from their soles. It is as if they are punishing themselves. The dance floor illustrates a gloomy picture of sorrow, decay and death due to the poet's use of expressions such as "Lovers dying," "children left unborn...," "beating their breasts," "wailed, and writhed," and "funeral pyre." Meanwhile, the picture reveals the misery of love and identity for the eunuchs. Furthermore, the poet has made the setting scorching through the repeated use of "hot." Davindra Kohl, comments on the sun, in "The Freak" composed by Das, as the symbol of sex, standing for the warmth and heat of lust [38]. Therefore, there is a subtle reference to sex and lust in the poem and it is connected to the freakish identity of the eunuchs. This freakishness is accentuated in the eunuchs by the tattoos on their cheeks. The tattoo is comparable to the scarlet letter ' $A$ ' that stands for adultery, a badge of sin or shame, on the dress of Hester Prynne, the protagonist of Nathaniel Hawthorne's The Scarlet Letter. Therefore, the dance of the eunuchs is only an 
external show to hide what they lack, as it is for Das who "flaunt[s], at/Times a grand, flamboyant lust" to save [her] face." [39].

\subsection{Asserting the Self}

Subjective writing is a notable technique used by confessional writers and this is very much in evidence in the poetry of Kamala Das. Through the extended use of the personal pronoun 'I,' the poet reveals her own existence by publicising her personal experiences and subjective feelings. Meanwhile, the writer projects the self to indicate the identity of every woman. The following lines from "An Introduction" provides an example:

...I met a man, loved him...

It is I who drink lonely

Drinks at twelve, midnight, in hotels of strange towns,

It is I who laugh, it is I who make love

And then, feel sham, it is I who lie dying

With a rattle in my throat. I am a sinner,

I am a saint. I am the beloved and the

Betrayed... [40]

The 'I' suggests a dual implication in the poet's search to explore the self. The first 'I' refers to Das as a woman who is beloved, she feels ashamed of her sins, but is no more than an object. The second ' $\mathrm{I}$ ' is Das as a poet who breaks the boundaries of tradition in a subjective manner, therefore she is betrayed by the patriarchal institution, yet she views herself as a heralding force of liberation and she is a saint in the eyes of women. "Loud Poster" is a highly confessional poem which indicates the beginning of Das' awakening and maturity of thought. The poem presents a good example of subjective writing:

I am today a creature turned inside

Out. To spread myself across wide highways

Of your thought, stranger, like a loud poster

Was always my desire, but all I

Do is lurk in shadows of cul de sac... ...I've

Spent long years trying to locate my mind...

...I have stretched my two dimensional

Nudity on sheets of weeklies, monthlies,

Quarterlies, a sad sacrifice. I've put

My private voice away, adopted the

Typewriter's click as my only speech... [41]

The poem, eloquently announces the idea of projecting the self as every woman. Das states that she has published her innermost personal feelings and deepest emotions in books and periodicals mainly to locate her real self. The implication is that there is no boundary between private and public. The poet also attempts to voice the silent suffering of other women like her. In the last three lines, Das makes a contrast between private and public to say that she has paid dearly for lending her name to this cause.

\section{10. Seeking Death}

Death is another dominant theme in the poetry of Das and it is harkened back with more frequency, as the writer composes her last volumes. According to R. K. Mishra, this shift of mood in the poetry of Das is a transformation of the image of love into an irresistible image of death [42]. "The Suicide" is a direct expression of this idea in the poetry of Das:

I tell you, sea, 


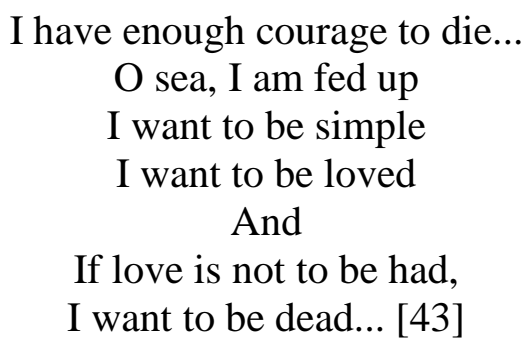

In the above lines, Das prefers to die instead of living a life "bereft of love." She expresses her desire for death in a highly subjective manner by using the pronoun 'I.' "The Wild Bougainvillea," reveals the poet's mental distress in her longing for love. Yet, the poem displays other confessional elements such as decay, death and destruction:

... where the barges

Float, their undersides rotting and the garbage

Rot, and the dead fish rot,

And, I smelt the smell of dying things and the

Heavy smell of rotting

Dead... [44]

The barge suggests a Shakespearean echo of Antony and Cleopatra where Enobarbus

describes Cleopatra on the barge9 to suggest her fatal power [45]. However, here the barge is inextricably connected to death and rot. In "I Shall Some Day", the dominant theme is death:

... I shall someday see

My world, de-fleshed, de-veined, de-blooded,

Just a skeletal thing, then shut my

Eyes and take refuge, if nowhere else'

Here in your nest of familiar scorn.... [46]

In this poem, death is seen as a gateway to freedom. When there is no flesh, veins, or blood, there will be no restriction, lust or oppression. The hyphens used in compound words above function as bridges that link or extend one concept to another. Another implication is that the constituents attached to the hyphens will not be meaningful and complete, if they are used by themselves. Therefore, death is supposed to compensate for the shortcomings in the life of the poet. "The Maggots" is a poem, on the separation of Radha and Krishna, which projects despair and death as its dominant theme:

That night in her husband's arms, Radha felt, So dead...

Do you mind my kisses, love? and she said, No, not at all, but thought, What is

It to the corpse if the maggots nip? [47]

Das, in this poem, portrays her ideal love through the Divine figures, Radha and Krishna. They are involved in making love and it is symbolised by a kiss. The poem recollects Andrew Marvell's "To His Coy Mistress" in which the lover insists on gaining physical pleasure out of their love because he believes that the beauty of his beloved will not last permanently, and it would be subject to decay and death. Similarly, "the maggots nip" symbolises death and the mortality of body. Radha's despondence is due to the transience of life and the belief that death disrupts the string of physical pleasure.

Das, like her contemporary American confessional writers, frequently contemplate death and suicide. Bruce King believes that the writings of Das reveal a dualism in which body and soul are contrasted. He also refers to a crisis of identity in Das due to the existence of contradictory parameters in her life including her name, aristocratic blood, family status in the South and her youth, on one hand, and her marriage and loveless life, on the other. Das decides to overcome the problem by embracing death [48]. 


\section{Conclusion}

The confessional poetry of Kamala Das is a versified reaction of this writer to discriminations, restrictions and turbulence that she has experienced in her life. This reaction often goes beyond the normal limits of tradition, convention and the established belief system of family, society, religion and culture. In case of women writers such reactions may be cast in feminist frames and sounds like a voicing protest, and resistance against patriarchal codes. Works of practitioners of this school, including Das reveal signs of "chaotic psychic situation" of the writer. This mentality makes the writer engaged in a continuant close and even "clinical observation" of the self [49]. Therefore, this poetry can be viewed as a means to redefine the wounded self, or the humiliated ' $i$ ' to the true, self-aware 'I,' in addition to its social challenges. This quality expands such poetry from the personal level to social and political levels. This is reflected in Das' "Someone Else's Song" in which Das appears as the spokesperson of her sex, or as every woman:

$$
\begin{gathered}
\text { I am a million, million people } \\
\text { Talking all at once... } \\
\text { I am a million, million silence } \\
\text { Strung like crystal beads } \\
\text { Onto someone else's } \\
\text { Song. [50] }
\end{gathered}
$$

\section{References}

[1] Farrokhzad, F., (2006), The collection of Forough's poems: Captive, Trans, M. Afshar, Tehran: Samir.

[2] Sameni, M. Hadi, (2012), unpublished Thesis, Madras University, pp.18-20.

[3] Ramadevi, N., (2007), Kamala Das and the confessional mode, In R. Mittapalli and P. P. Piciucco (Ed.), Kamala Das: A critical spectrum (pp. 140-146), New Delhi: Atlantic.

[4] Rosenthal, M. L., (1959), Poetry as Confession, The Nation, (189), 154-155.

[5] Dwivedi, A. N., (2006), Kamala Das and Her Poetry, New Delhi: Atlantic. p. 44.

[6] Sexton, A., (2004), Anne Sexton: A self-portrait in letters. Ed, Sexton, L. Gray and L. Ames, New York: Mariner Books.

[7] Usha, V.T., (2007), Literary paradigms of matriliny: Kamala Das's My story, In R. Mittapalli and P. P. Piciucco, (Ed.), Kamala Das: A critical spectrum (pp. 107-113), New Delhi: Atlantic.

[8] Kalpana, R. J. (2005). Feminist issues in Indian literature: Feminism and sexual politics. New Delhi: Prestige.

[9] Das, Kamala, (1996), Only the Soul Knows How to Sing: Selections from Kamala Das. Kottayam: D C Books, pp. 117-118

[10] ibid. 118

[11] ibid. 115

[12] ibid. 40

[13] Das, Kamala, (1965), Summer in Calcutta: Fifty Poems, New Delhi: Rajinder,.

[14] ibid. p. 59-60

[15] ibid. ibid. p. 59-60

[16] Bacon, Francis, (1865), "Of Marriage and Single Life," Bacon's Essays, Ed, Richard Whately and Franklin Fiske Heard, Boston: Lee and Shepard. p. 86

[17] Dwivedi, A. N., (2006), Kamala Das and Her Poetry, New Delhi: Atlantic. p. 44 
[18] Das, Kamala, (1999), The Old Playhouse and Other Poems, 3rd ed, Mumbai: Orient Longman.

[19] Borg, Marcus J., and N. T. Wright, (1999), The Meaning of Jesus: Two Visions. New York: Harper Collins. p. 183

[20] Das, Kamala, (1965), Summer in Calcutta: Fifty Poems, New Delhi: Rajinder,. p. 10

[21] Ramadevi, N., (2007), Kamala Das and the confessional mode, In R. Mittapalli and P. P. Piciucco (Ed.), Kamala Das: A critical spectrum (pp. 140-146), New Delhi: Atlantic. 141

[22] Das, Kamala, (1965), Summer in Calcutta: Fifty Poems, New Delhi: Rajinder, 1965. p .14

[23] Usha, V.T., (2007), Literary paradigms of matriliny: Kamala Das's My story. In R. Mittapalli and P. P. Piciucco, (Ed.), Kamala Das: A critical spectrum (p. 109), New Delhi: Atlantic.

[24] Das, Kamala, (1967), The Descendants, Calcutta: Writers Workshop. p.7

[25] ---, (1999), The Old Playhouse and Other Poems, 3rd ed, Mumbai: Orient Longman. pp. 21-22

[26] Dwivedi, A. N., (2006). Kamala Das and Her Poetry, New Delhi: Atlantic. p. 44

[27] Sameni, M. Hadi, (2012), "Searching the Self in Art and Life: A comparative Study of the Poetry of Kamela Das and Forough Farrokhzad." Diss. Madras U.

[28] Das, Kamala, (1967), The Descendants, Calcutta: Writers Workshop. pp.29-31

[29] ---, (2004), My Story. Kottayam: DC Books,. P 72

[30] ---, (1967), The Descendants. Calcutta: Writers Workshop. p.17

[31] ---. (1965), Summer in Calcutta: Fifty Poems. New Delhi: Rajinder. P28

[32] Hoagland, Sarah, Lucia, and Marilyn Frye, (2000), Feminist Interpretations of Mary Daly, University Park: Pennsylvania State UP. p232

[33] Das, Kamala, (1965), Summer in Calcutta: Fifty Poem, New Delhi: Rajinder. P26

[34] ---, Summer in Calcutta: Fifty Poems, New Delhi: Rajinder, 1965. p. 49

[35] Sameni, M. Hadi, (2012), "Searching the Self in Art and Life: A comparative Study of the Poetry of Kamela Das and Forough Farrokhzad." Diss. Madras U. p. 108

[36] Ebrahimian, Babak A. (2004), The Cinematic Theater. Maryland: Scarecrow,. p.22

[37] Das, Kamala, (1965), Summer in Calcutta: Fifty Poems, New Delhi: Rajinder. p9

[38] Kumar, C. Santhosh, (2007), "The Spirit of Emancipation in the Poetry of Kamala Das," New Perspectives on Indian English Literature, Ed, English Wing, Directorate of Distance Education, Annamalainagar: Annamalai UP. p93

[39] Das, Kamala. The Old Playhouse and Other Poems. 3rd ed. Mumbai: Orient Longman, 2004. p. 11

[40] ---. Summer in Calcutta: Fifty Poems, New Delhi: Rajinder, 1965. P. 60

[41] ibid. p23

[42] Mishra, R. K.., "Impact of Western Confessionalists on Kamala Das's Concept of Death and Suicide," The Literary Criterion, 2 (2010): p55.

[43] Das, Kamala, (1967), The Descendants, Calcutta: Writers Workshop. pp.1-2

[44] ---. Summer in Calcutta: Fifty Poems. New Delhi: Rajinder, 1965. P16

[45] Shakespeare, (1998), William, Antony and Cleopatra, Ed, Barbara Everett, New York: New American Library, 2.2. 37

[46] Das, Kamala, (1965), Summer in Calcutta: Fifty Poems. New Delhi: Rajinder. p. 52

[47] ibid. p22

[48] King, Bruce, (1989), "Women's Voices: Kamala Das, De Souza and Silgardo," Modern Indian Poetry in English, 2nd ed. Delhi: Oxford UP. P149

[49] Ramadevi, N., (2007), Kamala Das and the confessional mode, In R. Mittapalli and P. P. Piciucco (Ed.), Kamala Das: A critical spectrum (pp. 140-141). New Delhi: Atlantic. 
Bulletin de la Société Royale des Sciences de Liège, Vol. 85, 2016, p. 1628 - 1641

[50] Das, Kamala, (1965), Summer in Calcutta: Fifty Poems, New Delhi: Rajinder. P31 